ISBN 978-81-933894-1-6

2017 International Conference on Studies in Business Management, Law and Education

(SBMLE-17)

Kyoto (Japan) April 20-21, 2017

\title{
Development Of Skills And Critical Thinking In Junior High School (JHS) Students Towards Quality Basic Education In Ghana
}

\author{
Frank Okai Larbi \\ $\mathrm{PhD}$ in International and Comparative Education \\ Faculty of Education, Beijing Normal University
}

\begin{abstract}
Critical thinking and skill development are elements that cannot be overlooked in basic education. This study aims to discover public primary education along with other external factors that influence the development of skills and critical thinking, which have influence on employability, productivity and international competitiveness. It focuses on four major areas that influence skill development and critical thinking in basic school students: the curriculum, teaching methods, teacher/student relationships and extra-curricular activities. This paper focuses on the impediments to development of students' critical thinking and skills, and methods and theories to be applied in the classroom to develop students' critical thinking. In this study, I analyzed the junior high school (JHS) curriculum to identify the kind of skills it intends to develop, and observed teachers' pedagogy in the classroom. This study is an action research, which adopted interview, observation and document analysis to collect data. The population considered in this research includes headmasters, teachers and students, and parents from three public schools located in the Ashanti region of Ghana. The findings of this study will allow the creation of effective pedagogy aimed at learning with practical approach; learning that includes dynamic roles of classroom, teaching strategies and teaching and learning materials. Comprehensive recommendations have been provided for educational policy makers, educational directors, headmasters/mistress, and parents to cause a paradigm shift in the superannuated educational system in Ghana.
\end{abstract}

Keywords: critical thinking, engaged pedagogy, curriculum and basic education.

\section{Introduction}

Educational development promotes the formation of human capital and long-term productivity (Garcia, Gunawan and Jreij 2013 p. 4-5). It is an important tool for the optimum development of a nation's human or manpower resources, which contributes largely to a nation's total economic growth. Correspondingly, emerging economies pay attention to education and invest in education for the production of a skilled labor force. Educational planning, for this reason, is a vital part of the total economic and social planning that a nation undertakes periodically in order to improve the well being and living conditions of its people. Interestingly, each level of education yields a different effect on economic development; primary and secondary educations have a greater effect on basic worker productivity while higher education has a greater effect on technological innovation (Garcia, Gunawan and Jreij 2013 p.4). Curriculum is essential component of any educational process. It sets the parameters and gives directions to the educational process. It addresses questions such as what students should learn and be able to do, why, how, and how well.

The junior high school curriculum is loaded with much information, many subjects to be taught within limited period, therefore, teaching and learning becomes abstract, which does not enhance practical approach to 
involve students in teaching and learning process to increase their abilities to think critically, solve problems, and develop their skills and potentials. As a result, teaching becomes teacher centered and students become passive learners, which is termed as banking system of education (Freire, 1998). On the other hand, there is lack of technological equipments such as computers, projectors, and internet accessibilities in most of the public schools in Ghana, which makes it problematic to integrate information communication technology (ICT) in teaching and learning process. ICT is capable of enhancing students knowledge by engaging in discussions and exploring information technologically whiles they used experiences gained to help solve societal problems

Discovering the factors that thwart development of skills and critical thinking will assist the Ghanaian government in establishing educational policies, which aims to modify the curriculum and pedagogy to be geared towards student centered and problem posing type of education rather than teacher centered. These findings will allow for the creation of effective pedagogy aimed at learning with practical approach; learning that includes dynamic roles of classroom, teaching strategies and teaching and learning materials, the role of family and home environment and the role of the community. Discussions and analyses on the significance of skill development in students and economic development will prove insightful and relevant to economic and education issues in Ghana.

This study aims to discover public primary education along with other external factors that influence the development of skills and critical thinking, which has an influence on employability, productivity and international competitiveness. It focuses on four major areas that influence skill development and critical thinking in basic school students; the curriculum, teaching methods, teacher/student relationships and extracurricular activities. After in-depth analysis and investigation of the four major areas mentioned above, I will make a comprehensive recommendation for educational policy makers, educational directors, educationist, and headmasters/mistress to cause a significant change in the educational system in Ghana.

\subsection{Critical Thinking}

Barak and Dori (2009) view critical thinking as a skill that develops ones conscientiousness and enhances his/her thinking abilities. It entails coherency and reflective thought to make a person more responsible in his believes and actions. Phiters and Soden (2000) stated that critical thinking is the ability to evaluate how valid or reliable assertion by others are, and also the different source of information that are existing. Coronado (2011) added that critical thinking focuses on revealing poor reasoning and confronting the power structures that are in control of information, to ensure that the users are not misled. Critical thinking cannot be relegated to the background by educationist in Ghana. In this epoch of globalization, students must be taught to cope with the developmental trend and built their ability to intellectually compete internationally.

\subsection{Skills Shortage Dilemma}

An eroding education system funded and supported by the government of Ghana is contributing the skills shortage dilemma every year. Currently, the demand for specific occupational skills, soft skills and basic literacy and numeracy skills exceed the supply of these skills (Fazio and Pinder 2012). As a result, Ghana's economy is currently faced with many challenges, like high unemployment and brain drain, partly stemming from the lack of employable skills in the labor market. The skills shortage is undermining Ghana's opportunities for economic development. Currently, the Ghanaian government schools, specifically those in low-income communities and the rural areas are failing because children are not developing skills.

\subsection{Junior High School}

The junior high school (JHS) is a period of three years that is between 12 to 15 years old. JHS level is considered due to its sensitive part of the educational ladder, it is transition from basic school to senior high school. Students are expected to identify their skills and interest in their academic pursuit to specialize in the senior high school and above. The JHS curriculum is grouped into two parts, the compulsory subjects and the optional subjects. The subjects include English Language, Mathematics, Integrated Science, Social Studies, 
Basic Design Technology (BDT), Ghanaian language, Information Communication Technology (ICT) Religious and Moral Education (RME), French. All the above subjects are meant to develop students' skills and creativity, however, the reality is opposite. At the end of this level of education, one is required to sit for the Basic Education Certificate Examination (BECE) to ensure selection into the Senior High School/Technical Institutions.

\subsection{Curriculum Aspiration}

At the basic school level, the teaching of mathematics emphasizes mathematical knowledge and skills that should help the young person to develop competence in basic numeracy to function effectively in society. The skills taught include the ability to use numbers competently, read and interpret numeral data, reason logically, solve problems involving calculations and mathematical reasoning, as well as communicate effectively with other people using accurate mathematical data and interpretations. In addition, pupils are required to develop interest in the use of mathematics and the ability to conduct investigations using mathematical ideas. It is the acquisition of these qualities and the important quality of functional mathematics that education in Ghana aims to emphasize in the teaching and learning of mathematics in the school system (CRDD, 2007a).

It is expected that scientific experiences in school will cultivate in pupils an interest and love for science that will urge some of them to seek further studies in science as preparation for careers in science (Ampiah, 2010). Some of the positive attitudes and values pupils are expected to develop include the spirit of curiosity, creativity and critical thinking; skills, habits of mind and attitudes necessary for scientific inquiry; the spirit of curiosity for investigating and understanding their environment (Ampiah, 2010); communicate scientific ideas effectively; use scientific concepts for explaining their own lives and the world around them. For successful study of Science at the basic school level, the curriculum requires that pupils should have good observational skills, mathematical skills and communication skills (CRDD, 2007b).

As the official language, English is the language of government and administration. It is the language of commerce, the learned professions and the media. As an international language, it is the most widely used on the internet and in most parts of the world. In Ghana, English is the medium of instruction from Primary 4 in the school system. It is for these and other reasons that English Language is a major subject of study in Ghanaian schools. Teaching and learning English language in basic schools is aimed to develop in pupils, basic language skills such as listening, speaking, reading and writing. English proficiency acquired will help pupils to study other subjects as well as in the study of English at higher levels (CRDD, 2007c).

\section{Impediments to Skills Development and Critical Thinking in Basic Schools in Ghana}

\subsection{Inappropriate Teaching And Learning Methods}

One of the key hindrances that thwart the development of students' innovation and critical thinking is the process by which teaching and learning are carried out. Many teachers adapt teacher-centered method of teaching, characterized by banking system of education, which increases passivity of learners (Freire, 1970). In this situation, teaching and learning are not based on problem-posed education; therefore, learners do not enhance their skills and creativity through practice and involvement to solving problems in collaborative project works and assignments. Students learn new lessons by rote. There is tension and nervousness amongst students because they memorize ideas and concepts as preparedness towards terminal examinations and class test, therefore, they forget everything after writing examination. The nature of teaching and learning methods some teachers adopt in the classroom, impose fear and anxiety on students, which have negative influence on their self-realization and development. Unfortunately, many students are not able to apply knowledge gained in school for self and societal development; as a result, many institutions lack skilled personnel needed to carry out several projects. 


\subsection{Teacher-Student Relationship}

The authority teachers assume in class has led to unfavorable relationship between them and their students. Freire (1970) asserted that in the banking system of education, the teacher talks and the students listen meekly; the teacher chooses and enforces his choice, and students comply. Again, the teacher confuses the authority of knowledge with his own professional authority, which he sets in opposition to the freedom of the students; and the teacher is the Subject of the learning process, while the pupils are mere objects. It is argued that the above assertion constitute to marred and distorted relationships between students and teachers. Students are unable to confide in their teachers, and teachers do not sympathetically and maternally respond to the needs of their students. In situations like this, teachers fail to hold relevant guidance and counseling to build up students, therefore, anemic relationship between teachers and students does not encourage physiological developments of students.

\subsection{Lack of Teaching and Learning Materials}

Due to unavailability of teaching and learning materials (TMLs), teachers tend to abstractly carry out lessons. Students are not exposed to real objects or convincible evidence to completely comprehend ideas expressed in lessons taught. Seeing, touching, feeling and tasting are evidence of reality that will unleash students' criticalness on relevant matters in their societies. The reason for lack of teaching and learning materials in many public schools is attributed to inadequate finance released to schools for day-to-day administration. In subjects like Information Communication Technology (ICT), most schools do not have computers and internet facilities to enrich students and keep them abreast with technological advancement to influence and develop their critical mindset. This situation has caused many students to be technophobic.

\subsection{Limited Time Allocated For Extra-Curricular Activities}

Extra-curricular activities such as quiz and debate competitions, sports, cultural activities, and other relevant activities capable for developing students' creativity and enhancing cooperation between teachers and students have been overlooked in many schools. Less is done to enhance their psychomotor skills. This has led to difficulties of identification of talents and skills in students. It is proposed that schools should have ample time allocated for well-planned extra-curricular activities under proper supervision to achieve its purpose of enriching students' creativity and skills, and enhancing student-teacher and student-student relationship.

\subsection{Language of Instruction}

Students communicate and comprehend ideas better in their mother tongue (L1), however, the use of English as a language of instruction impedes students' understanding and their ability to make critical enquiries and contributions to matters arising in and out of the classroom. Some scholars argue that the language of instruction should be a mixture of English language and students' L1 to enable them make a substantive contribution, whiles it also help to enhance their understanding and comprehensively broaden their knowledge in the subject area. However, it is a challenge to adopt students' L1 as a language of instruction because of unavailability of textbooks and TLMs in that language.

\subsection{Poor Supervision of Teachers}

In many public schools in Ghana, headmasters and circuit supervisors do not supervise teachers regularly in the classroom to inspect and guide them on the use of appropriate teaching methods, the use of TLMs and proper engagement of students in the teaching and learning process. Poor supervision of teachers has led to mismanagement of classroom, mishandling of students by the use of punishment to intimidate them, and flaws in teaching. In addition, class exercises and assignments giving to students do not challenge them to unleash their research skills, and improve their ways of critical enquiries. Students are punished for low scores in class exercises and test, which intimidate them and diminish their interest to enthusiastically continue their education. Teachers should rather encourage and assist students with learning difficulties one-on-one instead of using punishment to inculcate fears in them, which will deter them from working diligently to augment their skills and 
creativity. Headmasters and circuit supervisors should not only be concerned with checking teachers' attendance and lesson notes, rather, much attention should be paid on teaching and learning in the classrooms to encourage teachers to be skillful and innovative to carry out lessons to help thrive students' creativity and skills.

\section{Constructionism and Engaged Pedagogy as Theories to Enhance Students' Critical Thinking and Engagement in the Classroom}

In this section, concepts are formulated to explain, predict, and understand phenomena of the ways students are taught and nurtured in JHS. First, "Constructionism is of the view that all knowledge, and therefore all meaningful reality as such, is contingent upon human practices, being constructed in and out of interaction between human beings and their world, and developed and transmitted within an essentially social context" (Crotty 1998, p. 42). It refers to how people in a society construct meaning through social interaction with others. In this phenomenon, children learn through participation and doing to create their own experience. In order to investigate how knowledge is constructed and understood in basic schools it is essential to find out the pedagogical approach adopted by teachers to interact with students and guide them to also interact amongst themselves to construct meanings of reality. Social constructionism focuses on daily interactions between people in a society and how they use language to construct reality, (Tom, 2012). Language is indispensable in the process of constructing reality; therefore, students should be able to express themselves well in the language of instruction to create conducive atmosphere to interact with each other. Unlike constructivism, whereby meaning is constructed based on individual's cognitive, constructionism deals with people-to-people constructing of meaning of reality. Hence, the idea of constructionism will help comprehend how the curriculum can be designed to promote interactional opportunity for students to construct meanings of reality in their societies. In addition, the epistemological conception of social constructionism will enlighten teachers on how to create a classroom that gives more room to engage students in teaching and learning process.

Second, according to bell hooks (1994), engaged pedagogy is an engagement of mind, body and spirit leading to a critical consciousness. Engage pedagogy opposes banking system of education whereby the teacher has all the power in the classroom and learners are considered as passive learners (Freire, 1970). According to Freire, knowledge is deposited in the minds of students; they do not critically reflect or argue on what is taught. This type of education is been practiced in many public schools in a Ghana. With the engaged pedagogy, the teacher is seen as a learner and learners are seen as teachers, dialogue is promoted between teachers and students and within the students themselves as well to construct meanings to reality in the society. "Engaged pedagogy assumes that every student has a valuable contribution to make to the learning process", (hooks 2010, p. 21). According the above assertion by bell hooks, when teachers teach based on this theory, students will take active part in the learning process to enhance their critical thinking. Engaged pedagogy helps to provide more comprehension on the need to enable teachers in Ghanaian basic schools to adopt or improve their pedagogies to create a classroom in which students will have the agency to interact with each other including the teacher to construct meaningful ideas.

\section{Conclusion and recommendations}

Curriculums, teaching methods and strategies have significant effects on students' skill development and critical thinking. Skills students develop in early stage in life have a positive growth on nation building, therefore, educationist and policy makers should revise the content of the curriculum, and set up programs to train teachers to be more creative and skillful in teaching and learning process. There is high level of unemployment in Ghana due to the dilemma of skills shortage; as a result, the public education system is in need of reform. First, basic schools must be more effective, having the ability to accomplish what it has set out to achieve. The system at the JHS level must not only produce literate graduates but also inspire the JHS graduates to achieve greater accomplishments having identified their careers and passions. The responsibility cannot be placed on formal education solely. Parents, relatives and caregivers must take the responsibility and contribute to 
their children's development of skills by assisting them with homeworks, motivating them to study and work hard in the classroom. Children take their support from home to the classroom and it influences their behavior. Some rare children perform exceptionally without any support. Those rare children have a different pattern of learning and their abilities can be seen as a gift. For many other children however, support and motivation is highly instrumental in facilitating learning and skill development. When Ghanaian students are deterred from their dreams and passions often times birthed at the basic School level, the labor market misses that skilled labor.

\section{Acknowledgement}

I sincerely express my profound gratitude to all those who tender heartedly assisted me to successfully complete this study. First, I thank my supervisor, Dr. Liu Qiang for his advice, encouragement and guidance towards research and academic writing skills to enhance my research potency. I am also grateful to my friend "Silas Bonney", for assisting me to collate data from all participants in Ghana. He helped with the realization of this research through diligence and commitment. I also express gratitude to all participants (headmasters, teachers, students and parents) who made information available for analysis in this study. Finally, thanks to all my friends and love ones who encouraged and supported me emotionally and intellectually to make this study a success.

\section{References}

[1] Ampiah, J.G. (2008). An investigation of provision of quality basic education in Ghana: A case study of selected schools in the Central Region. Journal of International Cooperation, 11 (3) 19-37.

[2] Barak, M. \& Dori, Y.J. (2009). Enhancing higher order thinking skills among inservice science teachers via embedded assessment. Journal of Science Teacher Education, 20, 459-474.

[3] Coronado, G. (2011). Web-based-research as critical pedagogy: A reflection on its application to undergraduate management education. Journal of University Teaching \& Learning Practice, 8, 1-15.

[4] CRDD (2007a). Teaching syllabus for integrated science (Primary 4-6). Accra: CRDD

[5] CRDD (2007b). Teaching syllabus for mathematics (Primary 1-6). Accra: CRDD

[6] CRDD (2007c). Teaching syllabus for English language (Primary 1-3). Accra: CRDD

[7] Crotty, M. (1998). The foundations of social research: meaning and perspective in the research.Sage Publication.

[8] Fazio, Maria, V., (2012). In pursuit of employable skills: understanding employers' demands: analysis of the Bahamas' 2012 wages \& productivity survey. Cataloging-in-Publication data provided by the Inter-American Development Bank Felipe Herrera Library, Retrieved from https://publications.iadb.org/bitstream/handle/11319/6686/In-Pursuit-of-Employable-Skills Understanding-EmployersDemands.pdf

[9] Freire, P. (1998). Chapter 1: Pedagogy of the oppressed. In P. Freire (Ed.), Pedagogy of the oppressed (pp. 43-70). New York, NY: Continuum.

[10] hooks, b (2010). bell hooks the teaching trilogy. 270 Madison Ave, New York, NY 10016. doi:ISBN1O: 0-415-968194 (hbk)

[11] John A. Hall, Ernest Gellner: an intellectual biography, London/New York: Verso 2010, xii + 400pp

[12] Julia, G., Devita, G., \& Vennessa, J. ( 2013). The influence of education on economic development. , , 12-16. Retrieved from https://oaktrust.library.tamu.edu/bitstream/handle/1969.1/148898/GARCIA-THESIS 2013.pdf?sequence $=1$

[13] Papert, S.A (1999), Mindstorms : Children, Computers, and Powerful Ideas (2nd edition), Basic Books (Short Disc); ISBN: 046504674

[14] Ministry of Education (July 2013). "Education Sector Performance Report" (PDF). Ministry of Education, Republic of Ghana. Retrieved 27 May 2014.

[15] Tom, A. (2012). What is Social Constructionism? Grounded theory review, 11(1), Retrieved from http://groundedtheoryreview.com/2012/06/01/what-is-social-constructionism/ 